\title{
Balance Weights in the Collection of the Anatolian Civilizations Museum in Ankara
}

\section{Oğuz Tekin}

\section{Q OpenEdition \\ 1 Journals}

\section{Electronic version}

URL: http://journals.openedition.org/anatoliaantiqua/383

DOI: 10.4000/anatoliaantiqua.383

\section{Publisher}

IFEA

\section{Printed version}

Date of publication: 1 May 2016

Number of pages: $211-222$

ISBN: 9782362450648

ISSN: 1018-1946

\section{Electronic reference}

Oğuz Tekin, "Balance Weights in the Collection of the Anatolian Civilizations Museum in Ankara", Anatolia Antiqua [Online], XXIV | 2016, Online since 11 December 2018, connection on 16 February 2021. URL: http://journals.openedition.org/anatoliaantiqua/383 ; DOI: https://doi.org/10.4000/ anatoliaantiqua.383 


\section{ANATOLIA ANTIQUA ESKI ANADOLU}

\section{XXIV}

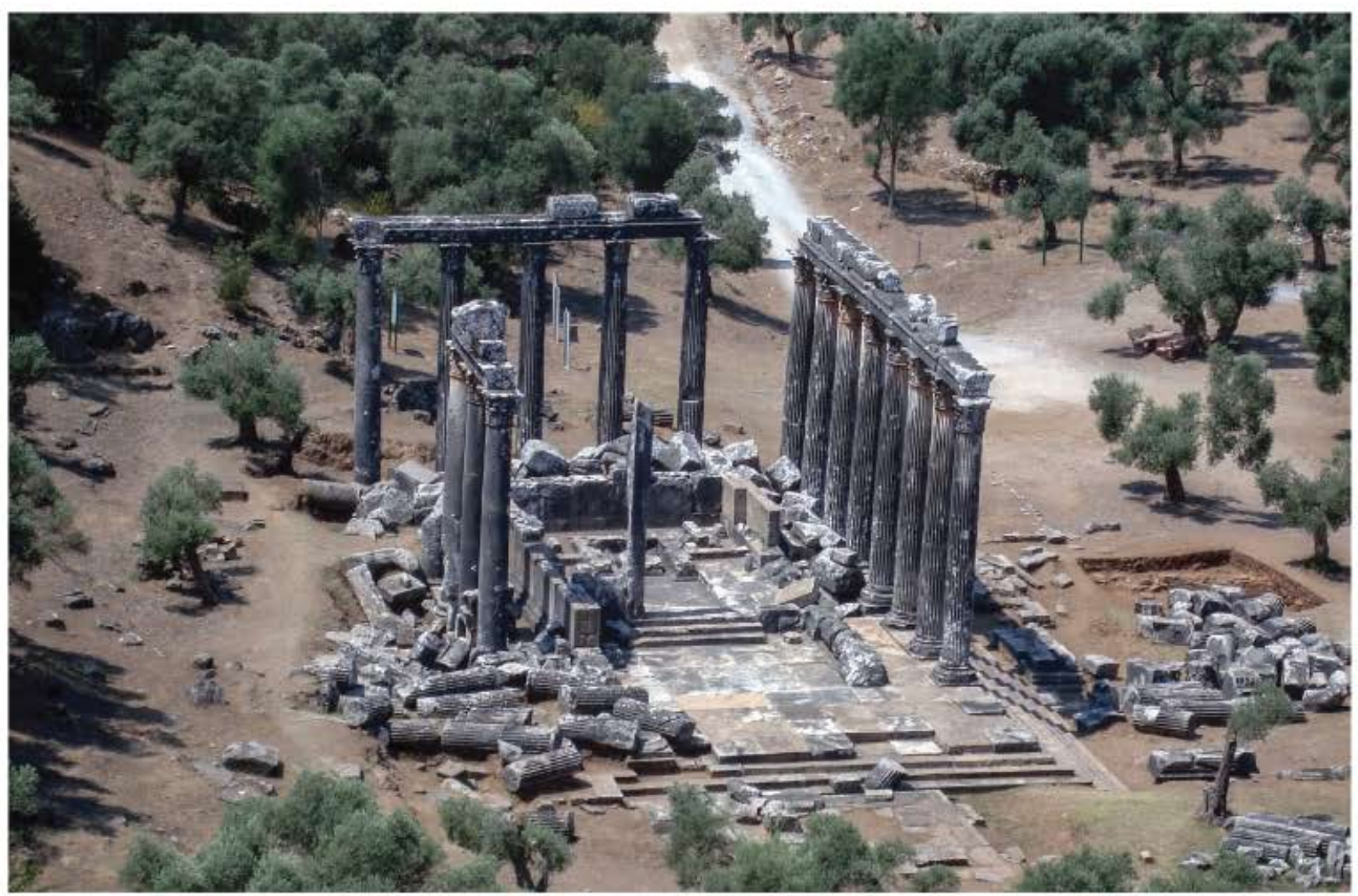

INSTITUT FRANÇAIS D'ETUDES ANATOLIENNES GEORGES-DUMEZIL

CNRS USR 3131

DE BOCCARD 


\section{TABLE DES MATIERES}

Ergul KODAS,

Le surmodelage du crâne au Néolithique au Proche-Orient : techniques de surmodelage et

expérimentations

Isabella CANEVA et Eric JEAN,

Mersin-Yumuktepe : une mise au point sur les derniers travaux

Turan EFE et Bérengère PERELLO,

Second Millenium site distribution and pottery of Inland Northwestern Anatolia

Antoine PEREZ,

Amida 6 : Antiochos IV, le "Hanigalbat" et la Sophène

Ergün LAFLI et Hadrien BRU,

Inscriptions et monuments funéraires gréco-romains d'Anatolie occidentale

Oğuz TEKİN et Aliye EROL-ÖZDİZBAY,

Coins from Allianoi excavations: Campaign of 2001

Nuran ŞAHIN,

Etude iconographique des monnaies autonomes frappées par Colophon-sur-Mer :

nouveaux acquis

Vera SAUER,

Konventionelle Individualität. Zur Münzprägung nordanatolischer Städte in der römischen

Kaiserzeit

Oğuz TEKIN,

Balance weights in the collection of the Anatolian Civilizations Museum in Ankara

\section{CHRONIQUES DES TRAVAUX ARCHEOLOGIQUES EN TURQUIE 2015}

Çiğdem MANER,

Preliminary report on the third season of the Konya-Ereğli Survey (KEYAR) 2015

Dominique BEYER, Isabelle CHALIER et Françoise KIRNER,

Rapport préliminaire sur les travaux de la mission archéologique de Zeyve Höyük-Porsuk 2015 ...

Sami PATACI et Ergün LAFLI,

Field surveys in Ardahan in 2015

Jean-Charles MORETTI avec la collaboration de Nicolas BRESCH, Isabel BONORA,

Jean-Jacques MALMARY et Olivier RISS,

Claros, le temple d'Apollon : travaux réalisés en 2015

Serdar Hakan ÖZTANER,

La basilique civile de Nysa du Méandre

Abuzer KIZIL, Koray KONUK, Patrice BRUN, Laurent CAPDETREY, Raymond DESCAT,

Pierre FROHLICH, Didier LAROCHE, Enora LE QUERE, Francis PROST, Baptiste VERGNAUD,

Eurômos : rapport préliminaire sur les travaux réalisés en 2015

O. HENRY et E. ANDERSON, Chr. BOST, Ö. ÇAKMAKLI, F. CEDERLING, A. COMMITO,

M. CORMIER-HUGUET, A. COUTELAS, A. DOLEA, D. ERGENÇ, A. FRECCERO,

A. FREJMAN, P. LEBOUTEILLER, F. LESGUER, D. LÖWENBORG, V. LUNGU,

Fr. MARCHAND-BEAULIEU, A. SITZ, P. DE STAEBLER, B. VERGNAUD, 


\section{Oğuz TEKİN*}

\section{BALANCE WEIGHTS IN THE COLLECTION OF THE ANATOLIAN CIVILIZATIONS MUSEUM IN ANKARA}

There have been nearly ninety balance weights in the collection of Anatolian Civilizations Museum in Ankara; the present article covers seventy-four of them ${ }^{1}$. Three weights $\left(\mathrm{N}^{\mathrm{o}} 1-3\right)$ date to the Late Classic / Early Hellenistic periods; two are Late Roman Imperial weights $\left(\mathrm{N}^{\circ} 4-5\right)$; seventeen are Early Byzantine weights $\left(\mathrm{N}^{\mathrm{o}} 6-22\right)$ and fifty-two are Islamic weights which date from the $10^{\text {th }}$ century through the early $20^{\text {th }}$ century $\left(\mathrm{N}^{\mathrm{o}} 23-74\right)$.

The denomination of the first weight $\left(\mathrm{N}^{\circ} 1\right)$ is clear since its masss corresponds its denominational mark $(\mathrm{H})$ on it. But since it does not bear any ethnic or symbol it is impossible to attribute it to any city. The folded and rounded corners are characteristic for the Classical and Hellenistic lead weights. There are a lot of examples with folded and rounded corners found in the excavations at the Athenian Agora $^{2}$. The second weight $\left(\mathrm{N}^{\circ} 2\right)$ is a hemimnaion according to its mass but the meaning of the large $\mathrm{M}$ on the top is not clear. If it is a hemimnaion then the $\mathrm{M}$ is not an initial of the denominational mark, instead it may be the initial of an ethnic but this is not certain. The meaning of the letter (inverted E? or $\mathrm{H}$ ) between the middle legs of the $\mathrm{M}$ is a key point to understand the top design. However the obscure letter may be a damaged $\mathrm{H}$; then one may read it as $\mathrm{H}+\mathrm{M}$ which stands for a hemimnaion. Anyway it is hard to attribute it to any city. The third weight $\left(\mathrm{N}^{\mathrm{o}} 3\right)$ is a tetarton (i.e. one-fourth of a mna) and it is hard also to attribute it to any city since it does not bear an ethnic. The symbol, i.e. shield (?), is a common symbol and can not be attributed to any city.
$\mathrm{N}^{\mathrm{o}}$ 4-5 are spherical weights doubly truncated on the top and bottom; they are bronze weights with lead core and characteristic for the Late Roman Period. These forms were replaced in the markets by the early Byzantine forms ( $\mathrm{N}^{\mathrm{o}}$ 6-22), i.e. square, discoid and octogonal bronze weights. Byzantine weights in the catalogue may be placed under two groups: Commercial weights $\left(\mathrm{N}^{0} 6-8,17\right)$ and coin weights $\left(\mathrm{N}^{\circ} 9-16,18-22\right)$. The majority of the weights in the catalogue are islamic (dirhams), i.e. Seljuks and Ottomans. Some are barrel-shaped ( $\mathrm{N}^{\mathrm{o}}$ 23-29); some are small square or discoid weights $\left(\mathrm{N}^{\circ} 30\right.$ 40) with bird's eye motifs; some are square prism or cubic in form $\left(\mathrm{N}^{\mathrm{o}} 41-50\right)$; some are the polyhedron weights which bear bird's eye motifs on their bodies ( $\mathrm{N}^{\circ}$ 51-61) and some polyhedron weights with triangular and square facets $\left(\mathrm{N}^{\circ} 62-63\right)$ and some are octogonal weights ( $\left.\mathrm{N}^{\mathrm{o}} 64-74\right)$.

As far as dating is concerned, the first three lead weights ( $\left.\mathrm{N}^{\mathrm{o}} 1-3\right)$ may be dated to the Late Classic and Early Hellenistic periods. The two spherical weights may be dated to the $4^{\text {th }}-5^{\text {th }}$ centuries A.D., i.e. they are Late Roman weights. Part of the Byzantine weights $\left(\mathrm{N}^{\mathrm{o}} 6-16\right)$ may be dated to the Early Byzantine Period of the $6^{\text {th }} 7^{\text {th }}$ centuries while one example $\left(\mathrm{N}^{\mathrm{o}} 21\right)$ may be dated to $5^{\text {th }}-6^{\text {th }}$ centuries; the others $\left(\mathrm{N}^{\mathrm{o}} 17-20,22\right)$ may be dated to the Middle Byzantine Period. Most of the Islamic weights $\left(\mathrm{N}^{\mathrm{o}}\right.$ 23-61) may be dated to the $10^{\text {th }}-13^{\text {th }} / 14^{\text {th }}$ centuries while some $\left(\mathrm{N}^{\mathrm{o}}\right.$ 62-74) may be dated to the $19^{\text {th }}$ early $20^{\text {th }}$ centuries, i.e. Late Ottoman Period.

\footnotetext{
*) Istanbul University, Ancient History Department, Beyazit-Istanbul.

1) I would like to thank Melih Arslan, the ex-Director of the Museum who permitted me to study and publish the weights. I would also thank Zehra F. Taşkıran and Mehtap Türkmen who facilitated my work and helped me during my studies in the museum. Eight of the seventy-four weights in the present catalogue were published previously by M. Acara Eser (see Acara Eser 2009).

2) Lang 1964: pls. 3-7.
} 


\section{CATALOGUE}

\section{Late Classic - Early Hellenistic Weights}

1) Inv. $N^{\circ} 164.11 .89$. Acquired in 1989. Find place: İzmir (Fig. 1)

Lead, $236.34 \mathrm{~g}, 47$ x 45 x $12 \mathrm{~mm}$. Square in form; corners are folded inwards. On the top, a large $\mathrm{H}$ which stands for hemimnaion ( $m$ n $a$ of $472.68 \mathrm{~g}$ ), in relief. The bottom is blank ${ }^{3}$.

2) Inv. $N^{\circ} 21.5 .96$. Acquired in 1996. Find place: uncertain (Fig. 2)

Lead, $223.16 \mathrm{~g}, 43 \times 44 \times 12 \mathrm{~mm}$. Square in form. On the top, a large $\mathrm{M}$ and an obscure letter (inverted $\mathrm{E}$ ? or $\mathrm{H}$ ) at the place where the middle legs of the $\mathrm{M}$ are crossed; all in relief. The bottom is blank. If the $\mathrm{M}$ stands for the denomination it should be a mna but the mass does not correspond to a mna; instead it corresponds to a hemimnaion (mna of $446.32 \mathrm{~g}$ ). So it is highly likely that the obscure letter is an $\mathrm{H}$; then $\mathrm{H}+\mathrm{M}$ stands for a hemimnaion.

3) Inv. $N^{\circ} 74.40 .03$. Acquired in 2003. Find place: Osmaniye (Fig. 3)

Lead, $107.29 \mathrm{~g}, 30 \times 30 \times 11 \mathrm{~mm}$. Square in form. On the top, an oval shield (?) in low-relief. The bottom is blank. Although its mass is somewhat low, it may be a tetarton (mna of $429.16 \mathrm{~g}$ ). Since it does not bear an ethnic it is hard to attribute it to any city.

\section{Late Roman Weights}

4) Inv. $N^{\circ}$ 15.1.03. Acquired in 2003. Find place: Sinop / Boyabat (Fig. 4)

Bronze with lead content, $159.40 \mathrm{~g}, 33 \times 27 \mathrm{~mm}$. In the form of a flattened sphere doubly truncated with centring points on the top and bottom; engraved on the top with the denominational mark $8 \mathrm{G}$; inlaid with silver which stands slightly proud of the surface. It is a six-uncia weight (uncia of $26.5 \mathrm{~g}$ ) . $^{4}$

5) Inv. $\mathrm{N}^{\circ}$ 84.16.73. Acquired in 1973. Find place: Konya/Kadınhanı (Fig. 5)

Bronze with lead content, $156.60 \mathrm{~g}, 36$ x $21 \mathrm{~mm}$. In the form of a flattened sphere doubly truncated with low centring points on the top and bottom; the body having a carinated profile; punched on the top with the denominational mark $\subseteq$ which denotes to a six-uncia or semis (litra of $313.2 \mathrm{~g}$ ).

\section{Byzantine Weights}

6) Inv. $\mathrm{N}^{\circ} 23.17 .03$. Acquired in 2003. Find place: Osmaniye (Fig. 6)

Bronze, $48.52 \mathrm{~g}, 28 \times 27 \times 8 \mathrm{~mm}$. Square in form with plain profile; engraved on the top with a Latin cross flanked by the denominational mark $\Gamma \mathrm{B}$ (hardly legible), originally not inlaid. The bottom is blank. It is a two-uncia weight (uncia of $24.26 \mathrm{~g}$ ) . $^{5}$.

7) Inv. $\mathrm{N}^{\circ}$ 20.3.68. Acquired in 1968. Find place: uncertain (Fig. 7)

Bronze, $52.02 \mathrm{~g}, 29 \times 29 \times 8 \mathrm{~mm}$. Square in form with plain profile. On the top, engraved with the denominational mark $\Gamma \mathrm{B}$ within a square border formed of engraved and punched geometric motifs; only vertical line of the letter $B$ is deeply engraved, the two semicircular parts are incised. Originally it may have been inlaid but the inlay is missing. The bottom is blank but irregular incisions. It is a two-uncia weight (uncia of $26.01 \mathrm{~g}$ ) . $^{6}$

8) Inv. $N^{\circ} 74.24 .03$. Acquired in 2003. Find place: Osmaniye (Fig. 8)

Bronze, $26.45 \mathrm{~g}, 25 \times 22 \times 5 \mathrm{~mm}$. Square in form with slightly convex profile. On the top, engraved with the denominational mark $\Gamma \mathrm{A}$, originally inlaid but the inlay is missing. The bottom is blank. It is a one-uncia weight ${ }^{7}$.

9) Inv. No 20.2.68. Acquired in 1968. Find place: uncertain (Fig. 9)

Bronze, $13.11 \mathrm{~g}, 18 \times 19 \times 4 \mathrm{~mm}$. Square in form with plain profile. Engraved and punched on the top with a wreath enclosing a cross above the denominational mark $\dot{\mathrm{N}} \Gamma$; both inlaid but the inlay is missing; one dot at each corner of the weight. It is a three-nomismata weight (nomisma of $4.37 \mathrm{~g}$ ). The bottom is blank ${ }^{8}$.

10) Inv. $\mathrm{N}^{\circ}$ 137.4.96. Acquired in 1996. Find place: Afyon/Dinar (Fig. 10)

Bronze, $10.21 \mathrm{~g}, 18 \times 18 \times 4 \mathrm{~mm}$. Square in form with plain profile. Engraved and punched on the top with the denominational mark N B; the bottom is blank. Although its mass is somewhat high, it is a two-nomismata weight (nomisma of $5.10 \mathrm{~g}$, "a high mass for two-nomismata").

11) Inv. $N^{\circ} 55.36 .03$. Acquired in 2003. Find place: Osmaniye (Fig. 11)

Bronze, $8.71 \mathrm{~g}, 15 \times 15 \times 4 \mathrm{~mm}$. Square in form with plain profile. Engraved on the top with a wreath enclosing

3) Tekin 2013: $n^{\circ}$ PMA 2236.

4) Published in Acara Eser 2009: ${ }^{\circ} 8$ (Fig. 12). Tekin 2015b: $n^{\text {os }}$ 6-11. For the spherical Late Roman weights cf. Pink 1938: $n^{\circ} 44$; Dürr 1964: $\mathrm{n}^{\circ}$ 261; Binsfeld 1990: $\mathrm{n}^{\text {os }}$ 18-20; Stiegemann 2001: $\mathrm{n}^{\circ}$ III.31 = Wamser 2004: $\mathrm{n}^{\circ}$ 790; Hendin 2007: $\mathrm{n}^{\circ}$ 328; Minchev 2008: 28, $\mathrm{n}^{\circ} 119$ and fig. 77; Jovanović 2012: $\mathrm{n}^{\text {os }} 3$-4; Tekin 2013: $\mathrm{n}^{\text {os }}$ 6-11.

5) Published in Acara Eser 2009: $\mathrm{n}^{\circ} 5$ (Fig. 8). Tekin 2013: $\mathrm{n}^{\circ} 097$ (denominational mark within wreath).

6) Tekin 2013: $\mathrm{n}^{\text {os }}$ 102-104 (not exact parallel, first two inlaid with silver).

7) Tekin and Baran Çelik 2013: n 284.

8) Breuer and Alenus-Lecerf 1965: fig. 22.9; Hendin 2007: nº 403; Qedar 1979: n 4172.Tekin and Baran Çelik 2013: ${ }^{\circ}$ 205; Tekin 2013: $\mathrm{n}^{\circ}$ 221; 2015b: $\mathrm{n}^{\circ} 221$.

9) Published in Acara Eser 2009: $n^{\circ} 4$ (Fig. 7) but misidentified as 3-nomismata. 


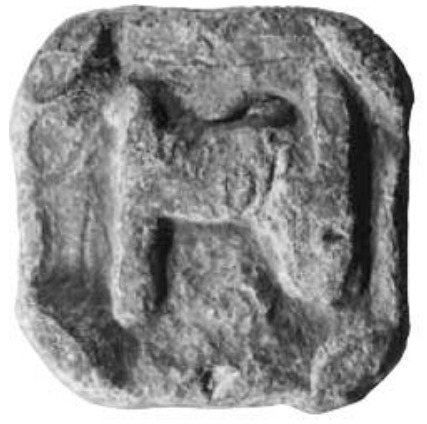

1

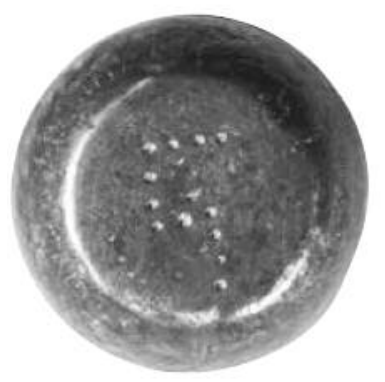

5

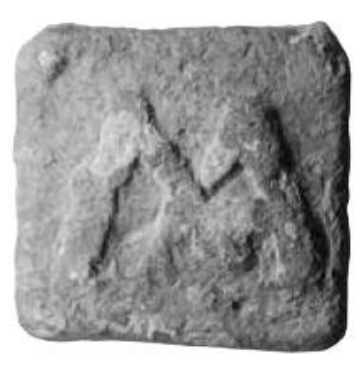

2

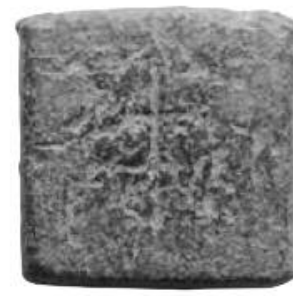

6

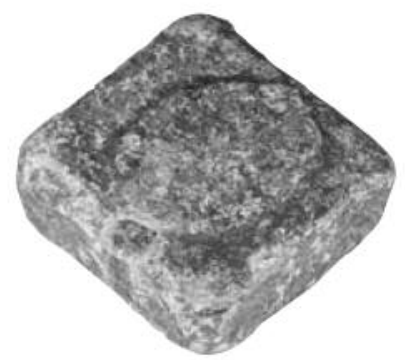

3

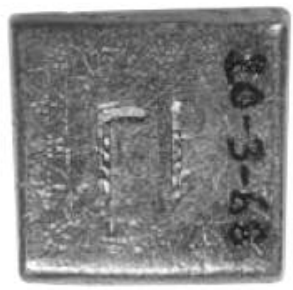

7

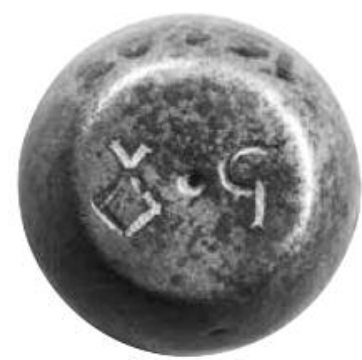

4

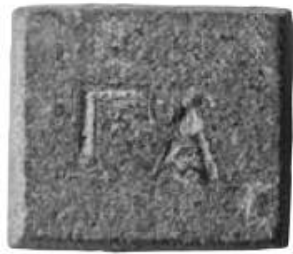

8

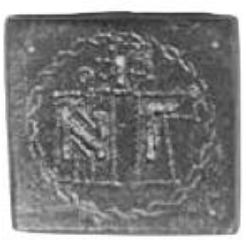

9

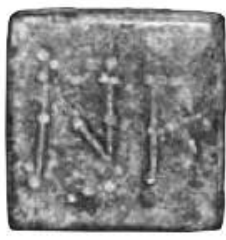

10

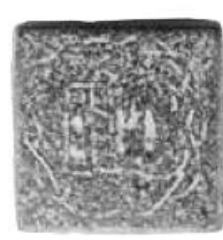

11

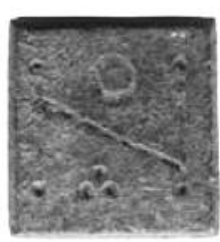

12

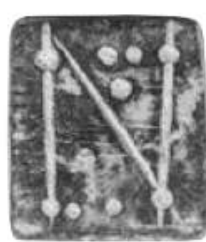

13

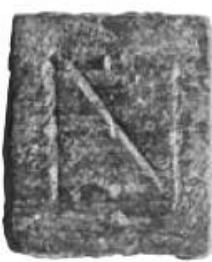

14

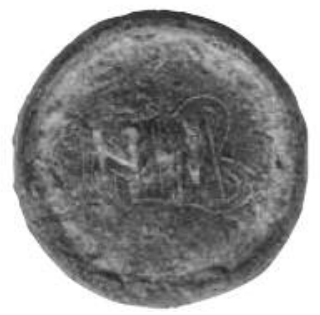

15

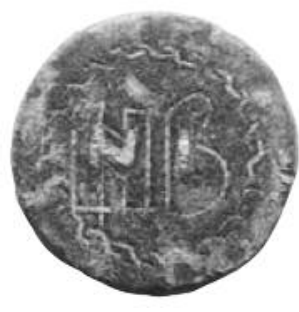

16

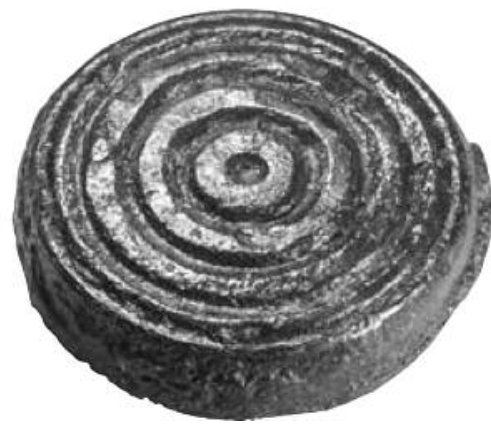

17

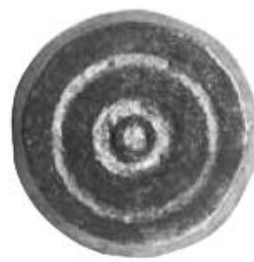

18 
the denominational mark $\mathrm{N} \mathrm{B}$; the bottom is blank. It is a two-nomismata (nomisma of $4.35 \mathrm{~g})^{10}$.

12) Inv. $N^{o} 74.26 .03$. Acquired in 2003. Find place: Osmaniye (Fig. 12)

Bronze, $4.39 \mathrm{~g}, 14 \times 15 \times 2 \mathrm{~mm}$. Square in form with plain profile. Engraved and punched on the top with the denominational mark $\dot{N}$ and below, three punched dots. The bottom is blank. It is a one-nomisma weight ${ }^{11}$.

13) Inv. $\mathrm{N}^{\circ}$ 55.33.03. Acquired in 2003. Find place: Osmaniye (Fig. 13)

Bronze, $4.37 \mathrm{~g}, 14 \times 12 \times 2 \mathrm{~mm}$. Square in form with plain profile. Engraved and punched on the top with the denominational mark N; at each angle of the N, a threedots motif. The bottom is blank. It is a one-nomisma weight $^{12}$.

14) Inv. $\mathrm{N}^{\circ}$ 55.35.03. Acquired in 2003. Find place: Osmaniye (Fig. 14)

Bronze, $4.49 \mathrm{~g}, 16$ × 13 × $2 \mathrm{~mm}$. Rectangular in form with plain profile. Engraved and punched on the top with the denominational mark $\mathrm{N}$; at each angle of the $\mathrm{N}$, a three-dots motif. The bottom is blank. It is a one-nomisma weight ${ }^{13}$.

15) Inv. $\mathrm{N}^{\mathrm{o}} 29.65 .04$. Acquired in 2004. Find place: Osmaniye (Fig. 15)

Bronze, $9.03 \mathrm{~g}, 20 \times 4 \mathrm{~mm}$. Discoid in form with raised rim and a thin centring point on the top; engraved on the top with a wreath enclosing the denominational mark $\mathrm{N} \mathrm{B}$, originally inlaid but the inlay is missing. It is a twonomismata weight (nomisma of $4.51 \mathrm{~g}$ ). Corroded $^{14}$.

16) Inv. $\mathrm{N}^{\circ} 29.66 .04$. Acquired in 2004. Find place: Osmaniye (Fig. 16)

Bronze, $8.90 \mathrm{~g}, 20 \times 3 \mathrm{~mm}$. Discoid in form with plain profile; engraved on the top with a wreath enclosing the denominational mark $\mathrm{N} \mathrm{B}$, originally inlaid but the inlay is missing. It is a two-nomismata weight (nomisma of $4.45 \mathrm{~g})$.

17) Inv. $\mathrm{N}^{\mathrm{o}}$ 110.1.89. Acquired in 1989. Find place: uncertain (Fig. 17)

Bronze, $733.6 \mathrm{~g}, 85 \times 17 \mathrm{~mm}$. Discoid in form with plain profile. On the top engraved concentric circles from the centring point through the edge. The bottom is blank but nailed at four point and a low hole at center. It is a commercial weight and it may be a thirty-uncia (uncia of $24.45 \mathrm{~g})^{15}$.
18) Inv. $N^{\circ} 20.6 .68$. Acquired in 1968. Find place: uncertain (Fig. 18)

Bronze, $4.20 \mathrm{~g}, 13 \times 4 \mathrm{~mm}$. Discoid in form with plain profile; two concentric grooves around a centring point on both sides. Its mass corresponds to a onenomisma ${ }^{16}$.

19) Inv. No 45.6.76. Acquired in 1976. Find place: uncertain (Fig. 19)

Bronze, $4.12 \mathrm{~g}, 13 \times 4 \mathrm{~mm}$. Discoid in form with carinated profile. On the top and bottom, four bird's eye motifs. Although the bird's eye motifs occur also on the islamic weights the mass of the present (and the following) weight corresponds to the Byzantine one-nomisma.

20) Inv. $N^{0}$ 20.7.68. Acquired in 1968. Find place: uncertain (Fig. 20)

Bronze, $4.02 \mathrm{~g}, 12 \times 3 \mathrm{~mm}$. Discoid in form with plain profile. On the top and bottom, two bird's eye motifs. Its mass corresponds to a one-nomisma.

21) Inv. $N^{0} 20.4 .68$. Acquired in 1968. Find place: uncertain (Fig. 21)

Bronze, $17.51 \mathrm{~g}, 21 \times 7 \mathrm{~mm}$. Octogonal in form with a centring point on the top; engraved with two circles on the top (one along the edge). At center, slightly engraved with a gamma-like mark. On the bottom deeply engraved irregular lines. Its form and mass correspond to a Byzantine weight; if so it is a four-nomismata weight (nomisma of $4.38 \mathrm{~g})$.

22) Inv. $N^{\circ} 126.41 .73$. Acquired in 1973. Find place: uncertain (Fig. 22)

Lead, $37.02 \mathrm{~g}, 23 \times 24 \times 7 \mathrm{~mm}$. Square in form with rounded corners; made from a seal-like object. Its mass corresponds to a nine-nomismata weight (nomisma of $4.11 \mathrm{~g})$ but not certain.

\section{Islamic ("Seljuks of Rum or Syria" and Ottomans)}

23) Inv. No 45.1.04. Acquired in 2004. Find place: Ankara/Polatlı (Fig. 23)

Bronze, $140.41 \mathrm{~g}, 34$ x $22 \mathrm{~mm}$. Barrel-shaped. The top and bottom are blank. A punchmark on one side. Its mass corresponds to a fifty-dirham (dirham of $2.80 \mathrm{~g}$ ).

24) Inv. $N^{\circ}$ 91.1.74. Acquired in 1974. Find place: uncertain (Fig. 24)

Bronze, $57.66 \mathrm{~g}, 27 \times 13 \mathrm{~mm}$. Barrel-shaped. On the top, illegible inscription in Arabic in relief. The bottom is blank. Circular groove near the edge on both sides. Its mass corresponds to a twenty-dirham (dirham of $2.88 \mathrm{~g})^{17}$.

10) Published in Acara Eser 2009: $\mathrm{n}^{\circ} 3$ (Fig. 6). Dalton 1901: $\mathrm{n}^{\circ}$ 442; Breuer and Alenus-Lecerf 1965: fig. 20.c and fig. 22.11; Qedar 1983: $n^{\circ}$ 5121; Bendall 1996: n 102; Wamser 2004: $n^{\circ}$ 803-804; Pottier 2004: pl. IV, $\mathrm{n}^{\circ}$ 5; Minchev 2008: $\mathrm{n}^{\circ}$ 73, fig. 43; Tekin and Baran Celik 2013: $\mathrm{n}^{\text {os }}$ 212-217; Tekin 2013: $\mathrm{n}^{\text {os }} 230-233 ; 2015$ b: 230-33.

11) For the variations of one-nomisma weights see Weber 2009.

12) Published in Acara Eser 2009: ${ }^{\circ} 1$ (Fig. 4). See also Weber 2009: $n^{\circ} 21$; Tekin 2013: $n^{\circ} 314 ; 2015 b: 312-14$.

13) Published in Acara Eser 2009: $n^{\circ} 2$ (Fig. 5). Tekin 2015b: 312-14.

14) Tekin 2013: $n^{\circ} 583$.

15) Published in Acara Eser 2009: $n^{\circ} 9$ (Fig. 13). Tekin 2015b: ${ }^{\circ} 666$ ff.

16) Tekin $2015 b: n^{\circ} 674$

17) Kürkman 2003: n 114 . 


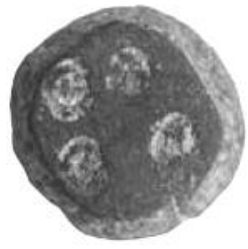

19
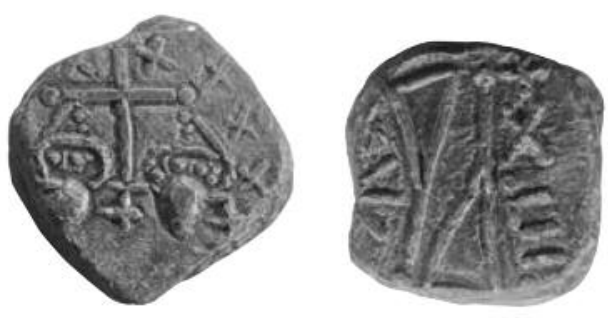

22
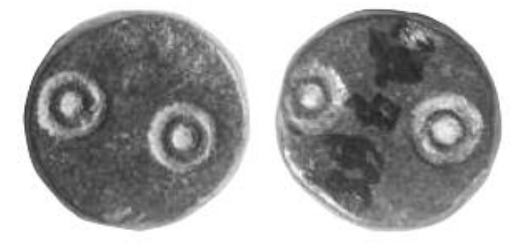

20

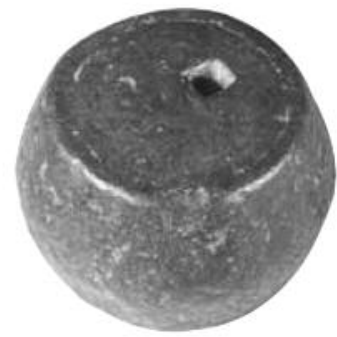

23

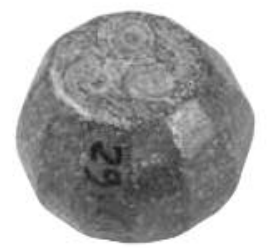

27

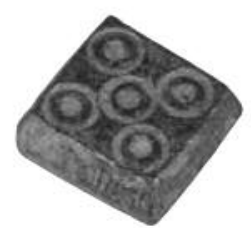

32
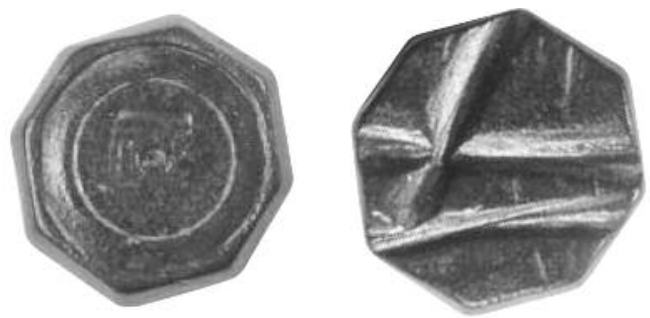

21
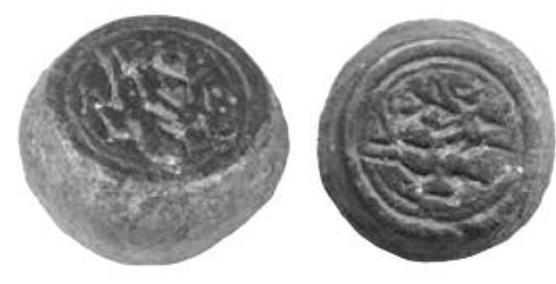

24

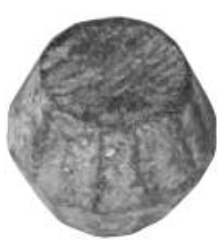

28

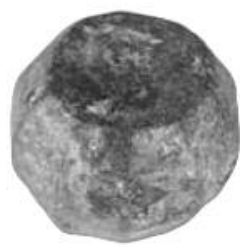

29

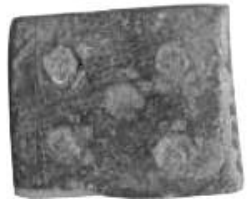

30

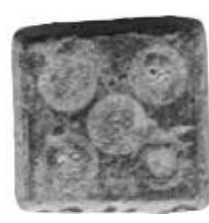

31

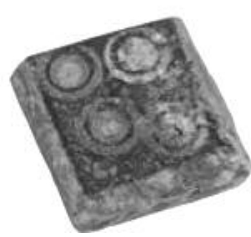

33 
25) Inv. No 14.145.04. Acquired in 2004. Find place: Osmaniye (Fig. 25)

Bronze, $14.62 \mathrm{~g}, 15 \times 11 \mathrm{~mm}$. Barrel-shaped with centring points and circular grooves near the edge on both sides. Its mass corresponds to a five-dirham (dirham of $2.92 \mathrm{~g})^{18}$.

26) Inv. $\mathrm{N}^{\mathrm{o}}$ 19.26.07. Acquired in 2007. Find place: uncertain (Fig. 26)

Bronze, $7.90 \mathrm{~g}, 14$ x 6 mm. Barrel-shaped. Circular groove near the edge on both sides. Its mass corresponds to a two-mithqal / dinar (mithqal of $3.95 \mathrm{~g}$ ) ${ }^{19}$.

27) Inv. $\mathrm{N}^{\circ} 29.68 .04$. Acquired in 2004. Find place: Osmaniye (Fig. 27)

Bronze, $57.91 \mathrm{~g}, 23 \times 19 \mathrm{~mm}$. Barrel-shaped with vertical ridges. Three bird's eye motifs on both sides. Its mass corresponds to a twenty-dirham (dirham of $2.89 \mathrm{~g}$ ).

28) Inv. $\mathrm{N}^{\circ} 14.140 .04$. Acquired in 2004. Find place: Osmaniye (Fig. 28)

Bronze, $28.83 \mathrm{~g}, 18 \times 16 \mathrm{~mm}$. Barrel-shaped with vertical ridges. Top and bottom are blank. Its mass corresponds to a ten-dirham (dirham of $2.88 \mathrm{~g})^{20}$.

29) Inv. $\mathrm{N}^{\circ}$ 29.67.04. Acquired in 2004. Find place: Osmaniye (Fig. 29)

Bronze, $28.64 \mathrm{~g}, 19 \times 14 \mathrm{~mm}$. Barrel-shaped with vertical ridges. On the top, double bird's eye motifs, the bottom is blank. Its mass corresponds to a ten-dirham (dirham of $2.86 \mathrm{~g})^{21}$.

30) Inv. $\mathrm{N}^{\circ} 14.147 .04$. Acquired in 2004. Find place: Osmaniye (Fig. 30)

Bronze, $5.97 \mathrm{~g}, 13 \times 12 \times 4 \mathrm{~mm}$. Square in form. Five bird's eye motifs on the top, the bottom is blank. Its mass corresponds to a two-dirham. (dirham of $2.98 \mathrm{~g}$ ) 22 .

31) Inv. $N^{\circ} 23.16 .03$. Acquired in 2003. Find place: Osmaniye (Fig. 31)

Bronze, $5.91 \mathrm{~g}, 13 \times 13$ x $4 \mathrm{~mm}$. Square in form. Five bird's eye motif on both sides. Its mass corresponds to a two-dirham (dirham of $2.95 \mathrm{~g}$ ) ${ }^{23}$.

32) Inv. $\mathrm{N}^{\circ}$ 114.13.09. Acquired in 2009. Find place: uncertain (Fig. 38)

Bronze, $5.72 \mathrm{~g}, 12 \times 12 \times 5 \mathrm{~mm}$. Square in form with carinated profile. Five bird's eye motifs on both sides. Its mass corresponds to a two-dirham (dirham of $2.86 \mathrm{~g}$ ) ${ }^{24}$.
33) Inv. $\mathrm{N}^{\circ}$ 24.44.06. Acquired in 2006. Find place: Osmaniye (Fig. 37)

Bronze, $5.78 \mathrm{~g}, 12 \times 12 \times 5 \mathrm{~mm}$. Square in form with carinated profile. Five bird's eye motifs on the top and four bird's eye motif on the bottom. Its mass corresponds to a two-dirham (dirham of $2.89 \mathrm{~g}$ ).

34) Inv. $\mathrm{N}^{\circ}$ 55.34.03. Acquired in 2003. Find place: Osmaniye (Fig. 32)

Bronze, $5.89 \mathrm{~g}, 12 \times 12 \times 5 \mathrm{~mm}$. Square in form. Four bird's eye motif on both sides. Its mass corresponds to a two-dirham (dirham of $2.94 \mathrm{~g}$ ).

35) Inv. $\mathrm{N}^{\circ}$ 29.63.04. Acquired in 2004. Find place: Osmaniye (Fig. 33)

Bronze, $5.80 \mathrm{~g}, 12 \times 12 \times 4 \mathrm{~mm}$. Square in form. Double bird's eye motif on both sides; on one side, also Arabic stamp. It may be read "ABD 7" (Abdullah 7) but if one may interpret the $\mathrm{V}$ at below as a lam $(j)$ placed diagonally then it may be read as "AD/L" (Adil=just) ${ }^{25}$. This countermark occurs also as ADL on the Byzantine folles of the $10^{\text {th }}$ $11^{\text {th }}$ centuries found in the eastern part of the Anatolia ${ }^{26}$. Its mass corresponds to a two-dirham (dirham of $2.90 \mathrm{~g}$ ) ${ }^{27}$.

36) Inv. $\mathrm{N}^{\circ}$ 23.15.03. Acquired in 2003. Find place: Osmaniye (Fig. 34)

Bronze, $5.65 \mathrm{~g}, 13 \times 13 \times 4 \mathrm{~mm}$. Square in form. Double bird's eye motif on both sides. Its mass corresponds to a two-dirham (dirham of $2.83 \mathrm{~g})^{28}$.

37) Inv. $\mathrm{N}^{\circ}$ 23.13.03. Acquired in 2003. Find place: Osmaniye (Fig. 35)

Bronze, $2.91 \mathrm{~g}, 10 \times 11 \times 3 \mathrm{~mm}$. Square in form. One bird's eye motif on both sides. Its mass corresponds to a one-dirham ${ }^{29}$.

38) Inv. $\mathrm{N}^{\circ} 29.62$ 04. Acquired in 2004. Find place: Osmaniye (Fig. 36)

Bronze, $2.87 \mathrm{~g}, 10 \times 10 \times 4 \mathrm{~mm}$. Square in form with carinated profile. One bird's eye motifs on both sides. Its mass corresponds to a one-dirham ${ }^{30}$.

39) Inv. $\mathrm{N}^{\circ}$ 41.32.79. Acquired in 1979. Find place: uncertain (Fig. 39)

Bronze, $20.54 \mathrm{~g}, 20 \times 9 \mathrm{~mm}$. Thick discoid in form. Four bird's eye motifs on both sides. Although its mass is somewhat low, it may be an eight-dirham weight (dirham of $2.57 \mathrm{~g}$ ).

18) Holland 1986: ${ }^{\circ}$ 81; 2009: ${ }^{\text {os }} 113-114$; Tekin and Baran Çelik 2013: $n^{\circ} 326$.

19) For similar forms see Holland 2009: $n^{\circ} 153$.

20) Kürkman 2003: n 109; Tekin and Baran Çelik 2013: no 333.

21) Holland 2009: $\mathrm{n}^{\circ}$ 148; Tekin and Baran Çelik 2013: $\mathrm{n}^{\circ} 126$ (five-dirham).

22) Holland 2009: $n^{\circ}$ 130; Tekin and Baran Çelik 2013: ${ }^{\circ} 314$.

23) Same refs. as above.

24) Same refs. as above.

25) For the similar examples of this countermark cf. Kürkman 2003: $n^{\circ} 85$ (read as Muhammed); Tekin and Merzeci 2012: $n^{\circ}$ 104, 107 and 115 (read as Abd 7).

26) Lowick 1977: $\mathrm{n}^{\text {os }} 10-11$ in the Table; Tekin 1996.

27) Kürkman 2003: $n^{\circ}$ 89; Tekin and Merzeci 2012: ${ }^{\text {os }}$ 99-100, 103, 108, 120; Tekin and Baran Çelik 2013: $\mathrm{n}^{\circ} 313$ (different denominations).

28) Same refs. as above.

29) Same refs. as above.

30) Tekin and Merzeci 2012: $\mathrm{n}^{\text {os }}$ 113, 116-119; Tekin and Baran Çelik 2013: $\mathrm{n}^{\circ} 312$ 


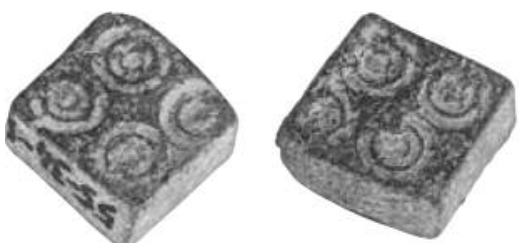

34
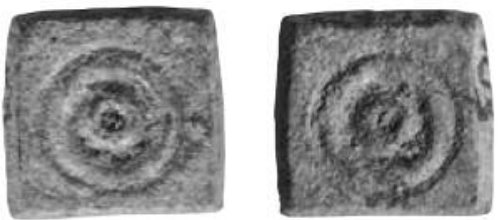

37
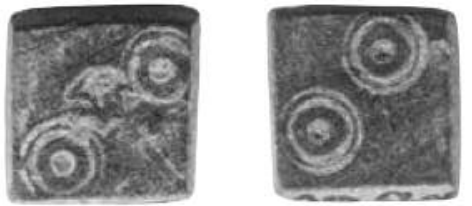

35
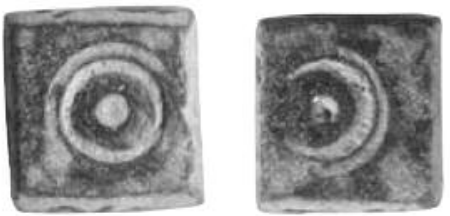

38
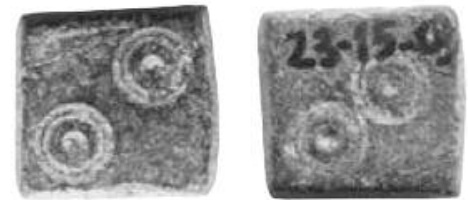

36
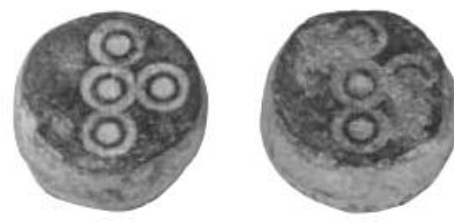

39
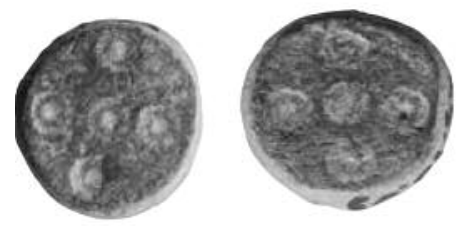

40

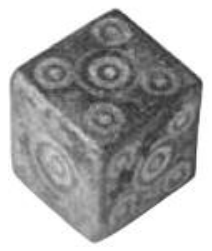

45

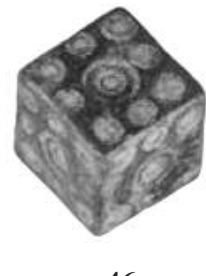

46

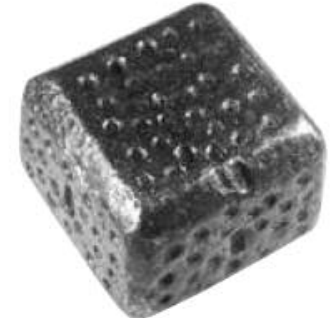

41

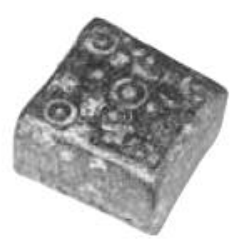

42

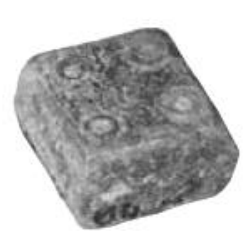

43

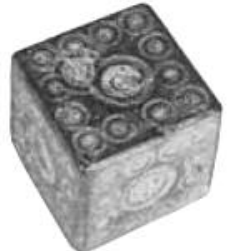

44

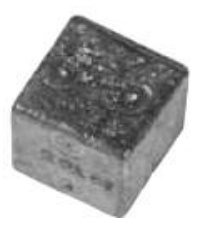

47

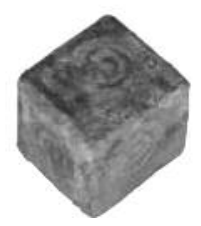

48

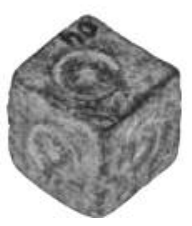

49

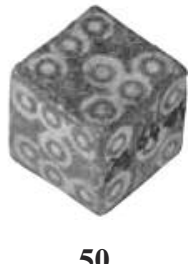

50 
40) Inv. $\mathrm{N}^{\circ}$ 23.10.03. Acquired in 2003. Find place: Osmaniye (Fig. 40)

Bronze, $8.39 \mathrm{~g}, 15$ x $5 \mathrm{~mm}$. Discoid in form. Five bird's eye motifs on both sides. Its mass corresponds to a three-dirham weight (dirham of $2.79 \mathrm{~g}$ ). Alternatively its mass also correponds to a two-mithqal (mithqal of 4.20 $\mathrm{g})$.

41) Inv. $\mathrm{N}^{\circ}$ 84.15.73. Acquired in 1973. Find place: Konya/Kadınhanı (Fig. 41)

Bronze, $294.5 \mathrm{~g}, 38$ x 39 x $29 \mathrm{~mm}$. Square prism in form with bevelled edges. All faces are full of punched dots and some stamps. Its mass corresponds to a 100-dirham weight (dirham of $2.94 \mathrm{~g}$ ).

42) Inv. $N^{o} 114.14 .09$. Acquired in 2009. Find place: uncertain (Fig. 42)

Bronze, $14.63 \mathrm{~g}, 13$ × 14 × $9 \mathrm{~mm}$. Square prism in form. Eight bird's eye motifs on the top and bottom faces; sides are blank. Its mass corresponds to a five-dirham weight (dirham of $2.92 \mathrm{~g}$ ).

43) Inv. $N^{\circ} 14.146 .04$. Acquired in 2004. Find place: Osmaniye (Fig. 43)

Bronze, $14.35 \mathrm{~g}, 14 \times 15 \times 9 \mathrm{~mm}$. Square prism in form with carinated profile. Five bird's eye motifs on both sides. Its mass corresponds to a five-dirham (dirham of $2.87 \mathrm{~g})$.

44) Inv. $\mathrm{N}^{\mathrm{o}}$ 74.20.07. Acquired in 2007. Find place: uncertain (Fig. 44)

Bronze, $58.80 \mathrm{~g}, 20 \times 20 \times 18 \mathrm{~mm}$. Cubic in form. On all faces, twelve bird's eye motifs around the central bird's eye motif. Its mass corresponds to a twenty-dirham weight (dirham of $2.94 \mathrm{~g})^{31}$.

45) Inv. $\mathrm{N}^{\circ}$ 49.33.04. Acquired in 2004. Find place: Osmaniye (Fig. 45)

Bronze, $29.05 \mathrm{~g}, 15 \times 15 \times 15 \mathrm{~mm}$. Cubic in form. On the all faces have five bird's eye motifs and one face has one bird's eye motif. Its mass corresponds to a tendirham weight (dirham of $2.90 \mathrm{~g})^{32}$.

46) Inv. $\mathrm{N}^{\mathrm{o}} 74.25 .03$. Acquired in 2003. Find place: Osmaniye (Fig. 46)

Bronze, $28.98 \mathrm{~g}, 15 \times 15 \times 15 \mathrm{~mm}$. Cubic in form. Nine bird's eye motifs on four faces and seven bird's eye motifs on the two faces. Its mass corresponds to a ten-dirham weight (dirham of $2.90 \mathrm{~g}$ ).

47) Inv. $N^{\circ} 20.1 .68$. Acquired in 1968. Find place: uncertain (Fig. 47)

Bronze, $28.73 \mathrm{~g}, 14 \times 15$ x $15 \mathrm{~mm}$. Cubic in form. Double bird's eye motifs on each face. Its mass corresponds to a ten-dirham weight (dirham of $2.87 \mathrm{~g}$ ).
48) Inv. $\mathrm{N}^{\mathrm{o}}$ 24.43.06. Acquired in 2006. Find place: uncertain (Fig. 48)

Bronze, $14.47 \mathrm{~g}, 12$ x 12 x $12 \mathrm{~mm}$. Cubic in form. All faces have one large bird's eye motif except two sides. Its mass corresponds to a five-dirham weight (dirham of $2.89 \mathrm{~g})$.

49) Inv. $N^{o}$ 14.148.04. Acquired in 2004. Find place: Osmaniye (Fig. 49)

Bronze, $14.42 \mathrm{~g}, 12 \times 12 \times 12 \mathrm{~mm}$. Cubic in form. All faces have one bird's eye motif. Its mass corresponds to a five-dirham weight (dirham of $2.88 \mathrm{~g}$ ).

50) Inv. $\mathrm{N}^{\circ}$ 29.64.04. Acquired in 2004. Find place: Osmaniye (Fig. 50)

Bronze, $14.31 \mathrm{~g}, 12 \times 12 \times 12 \mathrm{~mm}$. Cubic in form. Seven bird's eye motifs on the four faces and five bird's eye motifs on the two faces. Its mass corresponds to a five-dirham weight (dirham of $2.86 \mathrm{~g}$ ).

51) Inv. $N^{o}$ 14.141.04. Acquired in 2004. Find place: Osmaniye (Fig. 51)

Bronze, $28.98 \mathrm{~g}, 19$ x $15 \mathrm{~mm}$. Polyhedron in form. Concentric circles on the top and bottom; all facets are full of bird's eye motifs. Its mass corresponds to a ten-dirham weight (dirham of $2.90 \mathrm{~g})^{33}$.

52) Inv. $\mathrm{N}^{\mathrm{o}}$ 17.42.08. Acquired in 2008. Find place: uncertain (Fig. 52)

Bronze, $29.00 \mathrm{~g}, 18 \times 16 \mathrm{~mm}$. Polyhedron in form. Concentric circles on the top and bottom; all facets are full of bird's eye motifs. Its mass corresponds to a ten-dirham weight (dirham of $2.90 \mathrm{~g}$ ).

53) Inv. $\mathrm{N}^{\mathrm{o}}$ 23.12.03. Acquired in 2003. Find place: Osmaniye (Fig. 53)

Bronze, $28.78 \mathrm{~g}, 19 \times 15 \mathrm{~mm}$. Polyhedron in form. Rosette motif on the top and bottom; all facets are full of bird's eye motifs. Its mass corresponds to a ten-dirham (dirham of $2.88 \mathrm{~g}$ ).

54) Inv. $\mathrm{N}^{\circ}$ 17.43.08. Acquired in 2008. Find place: uncertain (Fig. 54)

Bronze, $29.81 \mathrm{~g}, 20 \times 15 \mathrm{~mm}$. Polyhedron in form. One large bird's eye motif on the top and bottom; all facets are full of bird's eye motifs. Its mass corresponds to a ten-dirham (dirham of $2.98 \mathrm{~g}$ ).

55) Inv. $\mathrm{N}^{0}$ 55.31.03. Acquired in 2003. Find place: Osmaniye (Fig. 55)

Bronze, 29.80 g, 21 x 15 mm. Polyhedron in form. One large bird's eye motif on the top and bottom; all facets are full of bird's eye motifs. Its mass corresponds to a ten-dirham (dirham of $2.98 \mathrm{~g}$ ).

31) For cubic dirhams see Holland 2009: $\mathrm{n}^{\circ} 117 \mathrm{ff}$.

32) Tekin and Baran Çelik 2013: $\mathrm{n}^{\circ} 310$

33) For this weight and the similar following weights cf. Tekin and Merzeci 2012: $\mathrm{n}^{\circ} 129$ ff; Tekin and Baran Çelik 2013: $\mathrm{n}^{\circ} 335 \mathrm{ff}$ 


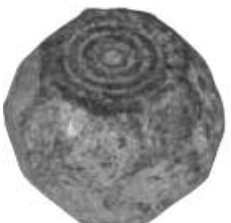

51

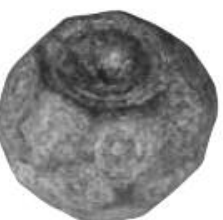

57

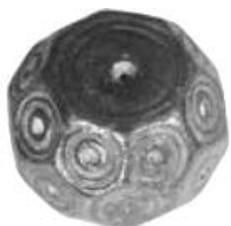

52

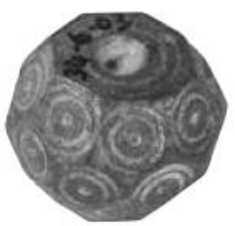

58

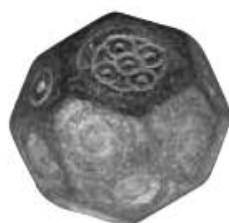

53

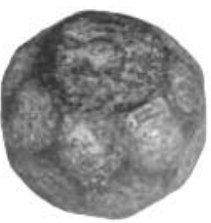

54

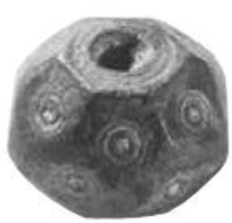

55

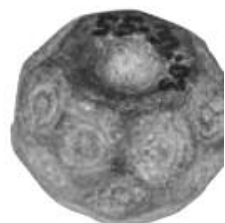

56

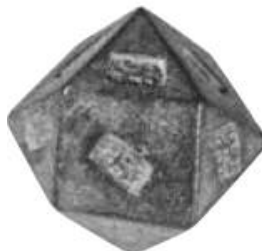

62

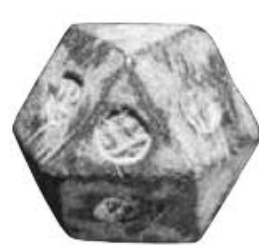

63

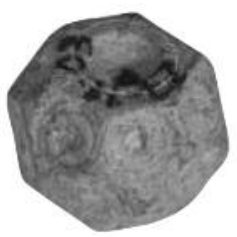

59

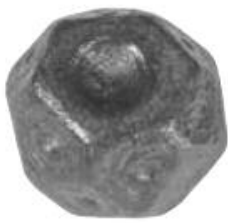

60

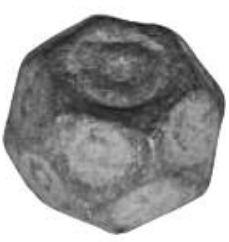

61

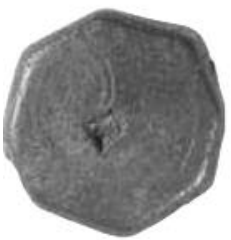

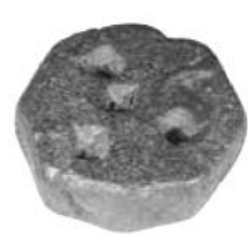

67

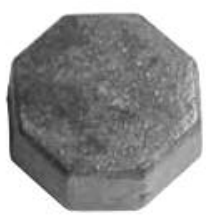

68

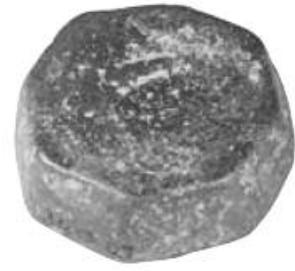

64

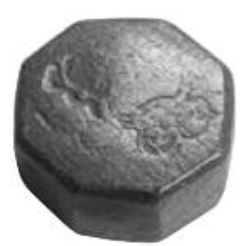

65

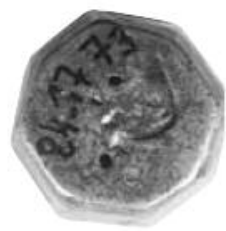

66

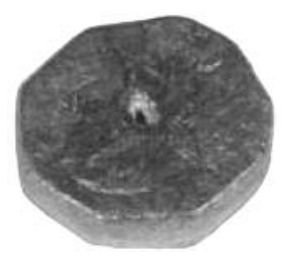

72

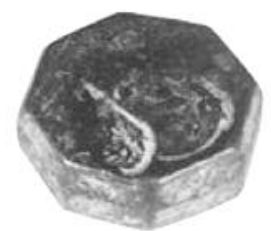

73

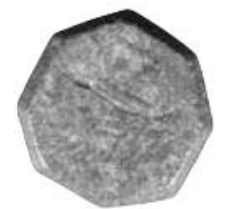

69

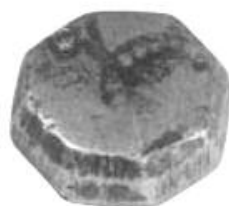

70

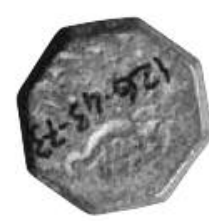

71 
56) Inv. $\mathrm{N}^{\mathrm{o}}$ 55.32. 03. Acquired in 2003. Find place: Osmaniye (Fig. 56)

Bronze, $28.93 \mathrm{~g}, 20 \times 15 \mathrm{~mm}$. Polyhedron in form. One large bird's eye motif on the top and bottom; all facets are full of bird's eye motifs. Its mass corresponds to a ten-dirham (dirham of $2.89 \mathrm{~g}$ ).

57) Inv. $N^{o}$ 14.142.04. Acquired in 2004. Find place: Osmaniye (Fig. 57)

Bronze, $27.33 \mathrm{~g}, 19 \times 15 \mathrm{~mm}$. Polyhedron in form. One large bird's eye motif on the top and bottom; all facets are full of bird's eye motifs. Its mass corresponds to a ten-dirham (dirham of $2.73 \mathrm{~g}$ ).

58) Inv. $N^{0} 34.6 .03$. Acquired in 2003. Find place: Osmaniye (Fig. 58)

Bronze, $29.16 \mathrm{~g}, 19 \times 15 \mathrm{~mm}$. Polyhedron in form. One large bird's eye motif on the top and bottom; all facets are full of bird's eye motifs. Its mass corresponds to a ten-dirham (dirham of $2.92 \mathrm{~g}$ ).

59) Inv. $\mathrm{N}^{\circ}$ 23.11.03. Acquired in 2003. Find place: Osmaniye (Fig. 59)

Bronze, $14.50 \mathrm{~g}, 16 \times 12 \mathrm{~mm}$. Polyhedron in form. One large bird's eye motif on the top and bottom; all facets are full of bird's eye motifs. Its mass corresponds to a five-dirham (dirham of $2.0 \mathrm{~g}$ ).

$60)$ Inv. $N^{\circ} 20.5 .68$. Acquired in 1968. Find place: uncertain (Fig. 60)

Bronze, $14.44 \mathrm{~g}, 14$ x $12 \mathrm{~mm}$. Polyhedron in form. One large bird's eye motif on the top and bottom; all facets are full of bird's eye motifs. Its mass corresponds to a five-dirham (dirham of $2.89 \mathrm{~g})^{34}$.

61) Inv. $N^{\circ}$ 14.143.04. Acquired in 2004. Find place: Osmaniye (Fig. 61)

Bronze, $14.22 \mathrm{~g}, 15 \times 12 \mathrm{~mm}$. Polyhedron in form. One large bird's eye motif on the top and bottom; all facets are full of bird's eye motifs. Its mass corresponds to a five-dirham (dirham of $2.84 \mathrm{~g}$ ).

62) Inv. $\mathrm{N}^{\mathrm{o}} 24.42 .06$. Acquired in 2006. Find place: Osmaniye (Fig. 63)

Bronze, $29.88 \mathrm{~g}, 22 \mathrm{~mm}$. Polyhedron in form with triangular and square facets. All facets have stamps with illegible arabic inscriptions or symbol ${ }^{35}$. Its mass corresponds to a ten-dirham (dirham of $2.99 \mathrm{~g})^{36}$.

63) Inv. $N^{\circ}$ 14.144.04. Acquired in 2004. Find place: Osmaniye (Fig. 63)

Bronze, $15.16 \mathrm{~g}, 18 \mathrm{~mm}$. Polyhedron in form with triangular and square facets. All facets have stamps with illegible arabic inscriptions. Its mass corresponds to a five-dirham (dirham of $3.03 \mathrm{~g}$ ).
64) Inv. $N^{\circ} 34.7 .03$. Acquired in 2003. Find place: Osmaniye (Fig. 64)

Bronze, $132.43 \mathrm{~g}, 40 \times 14 \mathrm{~mm}$. Octogonal prism in form. On the top, there is an obscure mark and the bottom is blank or illegible. Its mass corresponds to a forty-fivedirham (dirham of $2.94 \mathrm{~g}$ ) or alternatively to a Byzantine five-uncia (uncia of $26.48 \mathrm{~g}$ ). If it is a Byzantine weight it may be dated to the $5^{\text {th }}-6^{\text {th }}$ centuries but if it is an Ottoman weight then it may be dated to the $18^{\text {th }}-19^{\text {th }}$ centuries. The attribution is not certain ${ }^{37}$.

$65)$ Inv. $\mathrm{N}^{\mathrm{o}}$ 17.46.08. Acquired in 2008. Find place: uncertain (Fig. 65)

Bronze, $64.03 \mathrm{~g}, 27 \times 13 \mathrm{~mm}$. Octogonal prism in form. One side stamped with a tughra of Sultan (Abdulmecid?) and year (illegible). The other side is blank but bevelled edge. Its mass corresponds to a twenty-dirham (dirham of $3.20 \mathrm{~g}$ ).

66) Inv. $N^{o} 84.17 .73$. Acquired in 1973. Find place: Konya/Kadinhanı (Fig. 66)

Brass, $63.95 \mathrm{~g}, 27 \times 14 \mathrm{~mm}$. Octogonal prism in form. Illegible stamp on the top and bottom. Its mass corresponds to a twenty-dirham weight (dirham of $3.19 \mathrm{~g}$ ).

67) Inv. $\mathrm{N}^{\mathrm{0}}$ 17.45.08. Acquired in 2008. Find place: uncertain (Fig. 67)

Bronze, $55.03 \mathrm{~g}, 30 \times 10 \mathrm{~mm}$. Octogonal prism in form. Both faces are blank but on one side one punchmark and illegible tughra and four large punchmarks on the other side. Its mass corresponds to a twenty-dirham (dirham of $2.75 \mathrm{~g}$ ).

68) Inv. $\mathrm{N}^{\mathrm{o}}$ 126.42.73. Acquired in 1973. Find place: uncertain (Fig. 68)

Bronze, $32.23 \mathrm{~g}, 22 \times 10 \mathrm{~mm}$. Octogonal prism in form. Top and bottom are blank. Its mass corresponds to a ten-dirham weight (dirhem of $3.22 \mathrm{~g}$ ).

69) Inv. $N^{\circ} 126.45 .73$. Acquired in 1973. Find place: uncertain (Fig. 69)

Bronze, $15.78 \mathrm{~g}, 18 \times 7 \mathrm{~mm}$. Octogonal prism in form. On one face, obscure stamp. Its mass corresponds to a five-dirham weight (dirham of $3.15 \mathrm{~g}$ ).

70) Inv. $\mathrm{N}^{\mathrm{0}}$ 17.44.08. Acquired in 2008. Find place: uncertain (Fig. 70)

Brass, $15.69 \mathrm{~g}, 19 \times 6 \mathrm{~mm}$. Octogonal prism in form. One side stamped with a semicircular dotted motif. The other side is blank. Its mass corresponds to a five-dirham weight (dirham of $3.13 \mathrm{~g}$ ).

34) Tekin and Merzeci 2012: $\mathrm{n}^{\circ} 143 \mathrm{ff}$; Tekin and Baran Çelik 2013: $\mathrm{n}^{\circ} 339 \mathrm{ff}$.

35) For a similar countermark on Byzantine folles cf. Lowick et al. 1977: $\mathrm{n}^{\circ} 26$ in the Table

36) For this weight and the similar following weight cf. Tekin and Merzeci 2012: $\mathrm{n}^{\circ} 161$; Tekin and Baran Celik $2013: \mathrm{n}^{\circ} 353 \mathrm{ff}$.

37) Published in Acara Eser 2009: $n^{\circ} 7$ (Fig. 11). For the Islamic octagonal weights in different units see Kürkman 2003: ${ }^{\text {os }} 200$, 207-208, 221-225, 231-232, 310, 326-328; Tekin and Merzeci 2012: $\mathrm{n}^{\text {os }}$ 159-160; Tekin and Baran Çelik 2013: $\mathrm{n}^{\circ} 425$ ff; Tekin 2015a: $\mathrm{n}^{\circ} 30$; Custurea 1995-1996: p. 327, nº 4; Isler 1999: fig. 1. 
71) Inv. $\mathrm{N}^{\mathrm{o}} 126.43 .73$. Acquired in 1973. Find place: uncertain (Fig. 71)

Bronze, $15.59 \mathrm{~g}, 17 \times 8 \mathrm{~mm}$. Octogonal prism in form. On the top, cartouch and tughra. Its mass corresponds to a five-dirham weight (dirham of $3.12 \mathrm{~g}$ ).

72) Inv. $N^{\circ} 126.44 .73$. Acquired in 1973. Find place: uncertain (Fig. 72)

Bronze, $15.35 \mathrm{~g}, 18 \times 19 \times 7 \mathrm{~mm}$. Octogonal prism in form. Both faces are blank or illegible; central hole on both faces. Its mass corresponds to a five-dirham weight (dirham of $3.07 \mathrm{~g}$ ).

73) Inv. $\mathrm{N}^{\mathrm{o}}$ 17.39.08. Acquired in 2008. Find place: uncertain (Fig. 73)
Bronze, $16.43 \mathrm{~g}, 19 \times 7 \mathrm{~mm}$. Octogonal prism in form. On one side two stamps; one is I $\vee(=17=[12] 17$, Abdulmecid) in cartouch and the other is the tughra of Abdulaziz (?) Its mass corresponds to a five-dirham (dirham of $3.28 \mathrm{~g}$ ).

74) Inv. $\mathrm{N}^{\mathrm{o}}$ 17.40.08. Acquired in 2008. Find place: uncertain (Fig. 74)

Bronze, $15.99 \mathrm{~g}, 17$ x $9 \mathrm{~mm}$. Octogonal prism in form. Both sides are blank. Its mass corresponds to a fivedirham (dirham of $3.20 \mathrm{~g}$ ).

O.T. 


\section{BIBLIOGRAPHY}

Acara Eser, M., 2009: “Ankara Anadolu Medeniyetleri Müzesi'ndeki Sikke Kontrol Ağırlıkları ve Ticari Ağırlıklar”, in Alp, A.O. (ed.), Ebru Parman'a Armă̆an. Sanat Tarihi ve Arkeoloji Yazılarl, Ankara: 175-189.

Bendall, S., 1996: Byzantine Weights. An Introduction, London.

Binsfeld, W., 1990: "Römische Gewichte in Trier", Trierer Zeitschrift 53: 281-290.

Breuer, J. and Alenus-Lecerf, J., 1965: "La boîte à poids monétaires de Lutlommel”, Archaelogia Belgica 86: 103-116.

Custurea, G., 1995-1996: "Cateva ponduri mediavale descoperite in Dobrogea”, Pontica XVIII-XXIX: 323328.

Dalton, O.M., 1901: Catalogue of Early Christian Antiquities and Objects from the Christian East in the Department of British and Medieval Antiquities and Ethnography of the British Museum, London.

Dürr, N., 1964: Catalogue des poids byzantins. Musée d'Art et d'Histoire de Genève, Geneva.

Hendin, D., 2007: Ancient Scale Weights and PreCoinage Currency of the Near East, New York.

Holland, L., 1986: "Islamic Bronze Weights from Caesarea Maritima”, ANS Museum Notes 31: 171-201.

- 2009: Weights and Weight-like Objects from Caesarea Maritima, Hadera.

Isler, H.P., 1998: "Pesi di bronzo islamici dagli scavi di Monte Iato (Sicilia)", Numismatica e Antichità Classische XXVII: 345-369.

Jovanović, J., 2012: "Late Antique and Early Byzantine spherical bronze commercial weights housed in the Archaeological Museum in Split", VAPD 105: 179-200.

Kürkman, G. (ed.), 2003: Anatolian Weights and Measures (trs. P.M. Işın), Suna-Inan Kıraç Research Institute on Mediterranean Civilizations, Istanbul.

Lang, M., 1964: "Five Hellenistic Lead Weights", ANSMuseum Notes 14: 1-3.

Lowick, N.M, Bendall, S. and Whitting, P.D., The Mardin Hoard. Islamic Countermarks on Byzantine Folles, A.H. Baldwin and Sons Ltd., Hampshire.

Minchev, A., 2008: "Early Byzantine Weights Found in North-eastern Bulgaria and Some Notes on Their Production, Distribution and Use", Acta Varnaensis VII-2: 7-40,

Pink, K., 1938: Römische und byzantinische Gewichte in österreichischen Sammlungen, Wien.
Pottier, H., 2004: "Nouvelle approche de la livre byzantine du Ve au VII ${ }^{\mathrm{e}}$ siècle", RBN 150: 51-133.

Qedar, S., 1979: Münz Zentrum Auktion XXXVII. Gewichte aus Drei Jahrtausenden, Teil II, Köln.

- 1983: Gewichte aus Drei Jahrtausenden, Teil IV, Münz Zentrum XLIX. Auktion, Köln.

Stiegemann, C. (ed.), 2001: Byzanz. Das Licht aus dem Osten. Kunst und Alltag im Byzantinischen Reich vom 4. bis 15. Jahrhundert. Katalog der Ausstellung im Erzbi- schöflichen Diözesanmuseum Paderborn, Mainz.

Tekin, O., 1996: “Aşağı Anzaf (Van) Kazısından İslami Kontrmarklı Bir Bizans Sikkesi”, Toplumsal Tarih, December: 48-50.

Tekin, O. and Merzeci, A.M., 2012: Corpus Ponderum Antiquorum et Islamicorum. Turkey 1. The Collection of Klima Plus in Silifke Museum. Greek, Roman, Byzantine and Islamic Weights, Turkish Institute of Archaeology, Istanbul.

Tekin, O., 2013: Corpus Ponderum Antiquorum et Islamicorum. Turkey 3. Suna and Inan Kıraç Foundation Collection at the Pera Museum. Part 1. Greek and Roman Weights, Suna and İnan Kıraç Foundation, Istanbul.

- 2015: "Weights in the Museums of Denizli, Kütahya and Afyon", in Şimşek, C., Duman, B. and Konakç1, E. (eds.), Mustafa Büyükkolancı'ya Armağan / Essays in Honour of Mustafa Büyükkolancl, Istanbul: 613-629.

- 2015b: Corpus Ponderum Antiquorum et Islamicorum. Turkey 3. Suna and Inan Kıraç Foundation Collection at the Pera Museum. Part 2. Late Roman and Byzantine Weights, Suna and İnan Kıraç Foundation, Istanbul.

Tekin, O. and Baran Çelik, G., 2013: Corpus Ponderum Antiquorum et Islamicorum. Turkey 2. Istanbul Archaeological Museums. Greek, Roman, Byzantine and Islamic Weights in the Department of Metal Objects, Turkish Institute of Archaeology, Istanbul.

Wamser, L. (ed.), 2004: Die Welt von Byzanz - Europas östliches Erbe. Glanz, Krisen und Fortleben einer tausendjährigen Kultur, Schriftenreihe der Archäolo- gischen Staatssammlung 4, Stuttgart.

Weber, K., 2009: Byzantinische Münzgewichte Material-korpus für 1-nomisma-Gewichte, Mass und Gewicht, Beihefte zur Zeitschrift für Metrologie, Schwelm. 


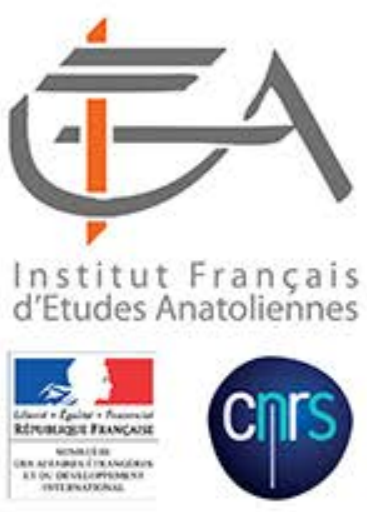

Eurômos : le temple de Zeus vu de l'Est (cliché Sönmez Alemdar).

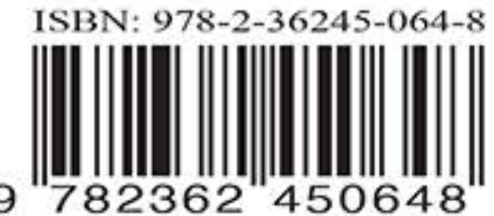

